\title{
Analysis of technical condition of footbridges over the railways in danger of collapse
}

\author{
Ryszard Chmielewski ${ }^{1, *}$, and Aleksandra $\mathrm{Bąk}^{1}$ \\ ${ }^{1}$ Military University of Technology, Faculty of Civil Engineering and Geodesy, Warszawa, Polska
}

\begin{abstract}
The article presents issues related to the maintenance of small engineering structures, such as footbridges over railways. These types of objects, usually are simple both in structure and construction. Design and construction errors usually, do not endanger the safety of the structure, although unrepaired ones may shorten the usability of the object. Particular attention should be paid to the elements of drainage, because effective rainwater management has significant influence to engineering structures usability. Regular inspections should ensure the operation of facilities that allow to avoid excessive deterioration of functional properties or maintaining objects in a proper technical and aesthetic condition. Structural collapses, that took place between 2014 and 2017 constitute only $2.85 \%$ [3], which indicates the improvement of quality of both design and implementation. However, it should be noted that maintenance errors are the second cause of structural failures. Therefore, it is necessary to emphasize crucial role of people performing periodic inspections of buildings, whose recommendations should be adhered and implemented by facility managers. The article presents examples of two footbridges over railways, that due to improper maintenance were excluded from use. Further operation of these footbridges threatened with construction collapse.
\end{abstract}

\section{Introduction}

Bridges are sensitive points in the road network, which often decide about usability of the roads. Therefore the bridges should be designed and constructed in the way that ensure their durability, understood as the usability of objects while maintaining the strength and performance characteristics, in the assumed period of use and level of maintenance. The meters of mentioned characteristics are the serviceability limit state and the ultimate limit state $[4,5]$.

Collapses of engineering structures are quite rare, although when they occur during operation, they always cause significant material damage and a relatively large number of fatalities and injuries $[6,7]$. The main reason of excluding buildings from use is their wear and tear, that is caused by exceeding the permissible number of load cycles (material fatigue) and degradation of the construction material. The issues of the life cycle of bridges attract great, interdisciplinary interest both of domestic and foreign specialists in construction, mechanics, materials science, computer science and management [5, 8-10].

\footnotetext{
*Corresponding author: ryszard.chmielewski@wat.edu.pl
} 
During periodic structural inspections the degree of degradation of the structure (e.g. by measuring corrosion losses) should be determined. These inspections should include checking the layout of the structure and the actual parameters of embedded materials $[10,11]$. Comprehensive assessment of the degree of degradation and determining causes of defects and damage allows to decide properly about the further use of the object.

\section{Description of the footbridges}

The first of the analysed objects is a footbridge, that was located at $5.297 \mathrm{~km}$ on the 017 Łódź Fabryczna - Koluszki railway line. This footbridge was crossing between platforms no. 1 and 2 at the Łódź Widzew railway station [12]. The footbridge was built in 1954 as reinforced concrete bridge frame with two stairways that descend to the platforms.

The overall length of the footbridge was $19.70 \mathrm{~m}$, while the length of flight stairs was $9.15 \mathrm{~m}$ each. The width of the footbridge deck was $2.70 \mathrm{~m}(2.60 \mathrm{~m}$ in the clearance of the passage for travellers). Square pillars were reinforced with bars with diameter of 18 to 24 $\mathrm{mm}$. In the spot footing and binders reinforcing bars with diameter of 12 to $22 \mathrm{~mm}$ and 6 $\mathrm{mm}$, were used respectively. The pier foundation were constructed as reinforced concrete, spread foundation, the founding depth $-160 \mathrm{~cm}$ to $195 \mathrm{~cm}$ below ground level. The foundations were built using concrete strength class $\mathrm{C} 8 / 10$, according to current standards.

The width of the stairs that leads to the platforms was $2.70 \mathrm{~m}(2.50 \mathrm{~m}$ width in the clearance of handrail). The height of the handrail of the footbridge was $110 \mathrm{~cm}$. The vertical clearance gauge under the upper deck of the footbridge was over $6.0 \mathrm{~m}$. The railway superstructure of all tracks was S49 type with reinforced concrete crosstie on railroad ballast. The horizontal gauges from the footbridge column place on the space between tracks no. 9 and 11 to the axis of these tracks were $2.11 \mathrm{~m}$ and $2.24 \mathrm{~m}$ respectively. The columns of the stairs that descend to the platforms were made as reinforced concrete with cross-sections: the column under the first landings were $30 \mathrm{~cm}$ x $30 \mathrm{~cm}$, the column over the second landing, at the beginning and the end of the upper deck $-50 \mathrm{~cm} \times 50 \mathrm{~cm}$ and the pillar supporting the top deck $-40 \mathrm{~cm} \times 40 \mathrm{~cm}$. The pillars that support both the deck of the footbridge and the stairs that descend to the platforms, were strengthened on the perimeter with a reinforced concrete layer, the dimensions of the pillars differ from the original dimensions presented in project documentation. The reason and the scope of this reinforcement is unknown.

The second of the analyzed objects is the footbridge located over the Odolany railway station at $2+530 \mathrm{~km}$ of railway line from Warszawa Odolany to Warszawa Gdańska [12]. The object was built in 1964, since then, the footbridge has been subject only to the basic maintenance operations consisting of painting the whole construction with laitance.

The structure of footbridge consists of sixteen spans with a static simply supported scheme and a theoretical span of $15.17 \mathrm{~m}$ each, the total length of the footbridge deck was $242.80 \mathrm{~m}$. Both stairways that descend from the footbridge, in the horizontal projection are $18.50 \mathrm{~m}$ long, the stairs from the Odolany railway station is made as a reinforced concrete structure, while the stairs from the Wola district was built as a steel structure with wooden landings. The load-bearing structure of the footbridge spans consists of two prestressed concrete girders with a height of $100 \mathrm{~cm}$ each. These girders support a footbridge built of prefabricated reinforced concrete slabs with a thickness of $20 \mathrm{~cm}$. The width of the upper deck and stairs in the clearance of steel handrail was $244 \mathrm{~cm}$. The structure of footbridge deck is supported by seventeen reinforced concrete pillars topped with capping beams. The footbridge deck is covered with a mastic asphalt surface, that supposed to act as an antiwater insulation. 


\section{Analysis of causes of footbridges damage}

The footbridge at Łódź Widzew railway station was designed in 1954. Analysis of design documentation has showed many inconsistencies and irregularities, among others [12]:

- asymmetrical distribution of the reinforcement bars in the pillars supporting the bridge deck structure, both in cross-section and over the length of columns,

- the drawings did not show the thickness of the reinforcement cover of all elements of the footbridge,

- improper selection of the solution for anchoring the handrail posts of the footbridge - the solution with the use of steel pipes required much more space; this solution (with horizontal steel sheets at the ends of pipes) led to local destruction of concrete in the cornices of the bridge deck in a very short period of time,

- improper anchorage of pillars in foundations (small amount of dowel bars),

- changing of the cross-section of the upper deck slab and the resulted in gathering of rainwater and various harmful chemicals dissolved in it,

- the use of a too low class of concrete for the construction of a structure used in an aggressive environment - class of designed concrete was (according to the old standatds) $\mathrm{R}_{\mathrm{w}}=170 \mathrm{~kg} / \mathrm{cm}^{2}$; which currently can correspond to the $\mathrm{B} 15$ concrete class $(\mathrm{C} 12 / 15)$.

National standards [13] are guidelines for the construction of bridges elements. These standards recommend the use at least B25 concrete class, for supports and foundations, for the elements up to $60 \mathrm{~cm}$ thick. In case of reinforced concrete spans and prefabricated elements with elements with thickness over $60 \mathrm{~cm}$, it is recommended to use the concrete class B30.

The design flaws were compounded by construction errors, for example dragging caused by the use of formwork made of poorly connected planks. In the Figure 1 the footbridge scheme with the directions of the photographic documentation is presented.

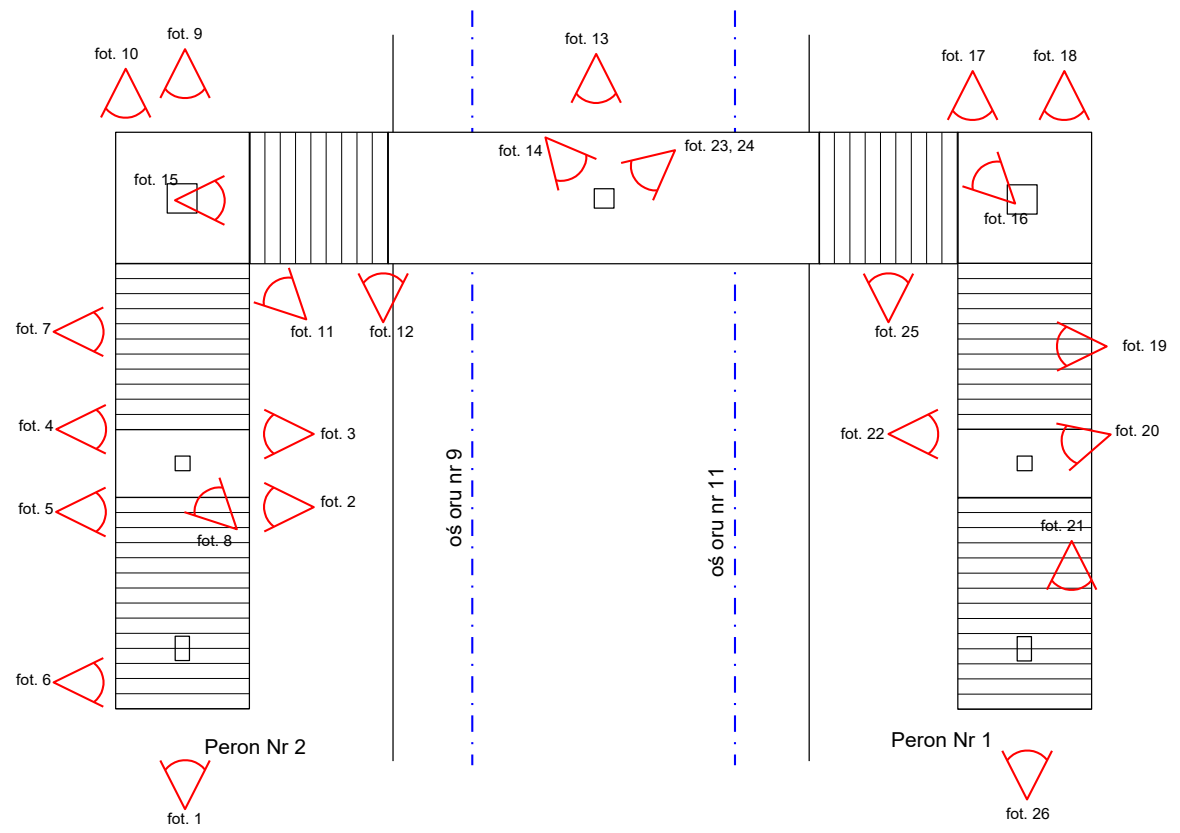

Fig. 1. Scheme of photo shots of photographic documentation [12]. 
The most important local destruction of structural elements included:

- losses of concrete over the entire thickness of the deck slab and stairs - for example: the opening, in the stoop of the deck above the platform no. 1, that was covered with metal sheet (e.g. figure 16 and 17 [12]) - Figure 2.

a)

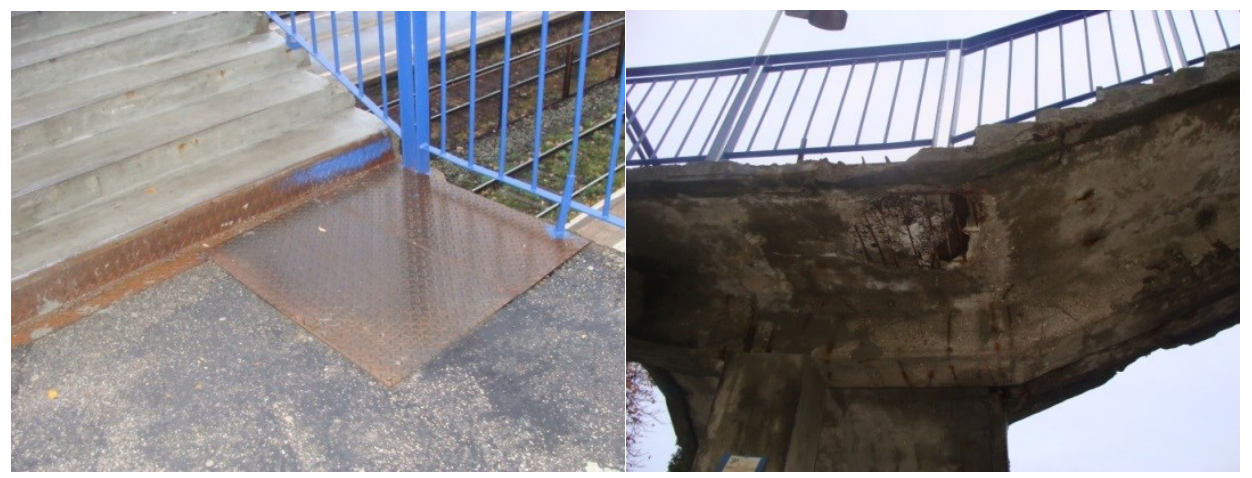

Fig. 2. The hole in the stoop above platform no. 1 a) covered from the top, b) view from below.

- narrow shrinkage cracks (up to $1 \mathrm{~mm}$ in width) occurring on the entire surface of the deck slab and stair slab, that were particularly visible during rainfall (e.g. figures 19 and 20 [12]) - Figure 3.

a)

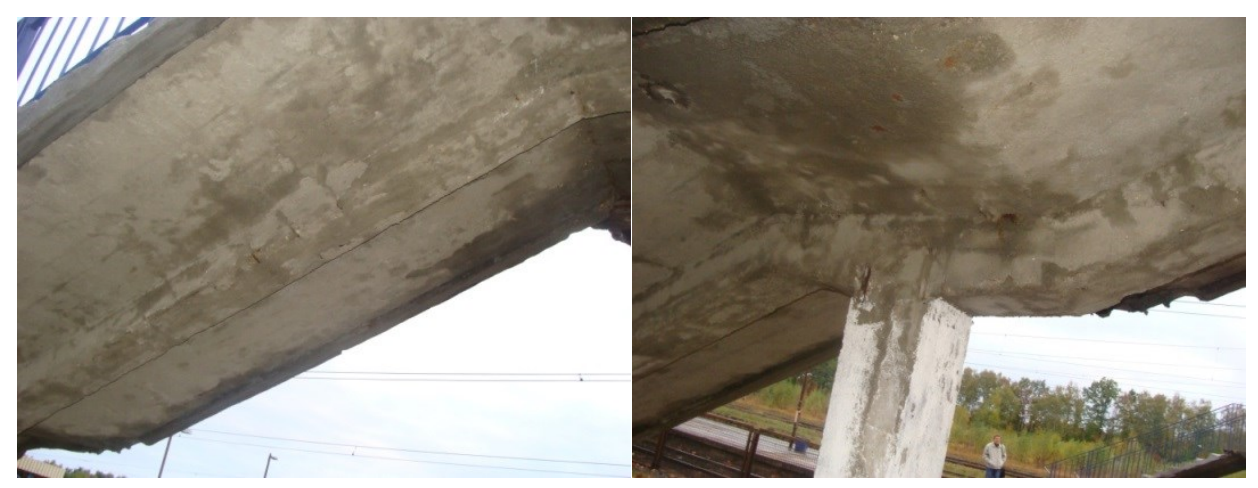

Fig. 3. a, b) Examples of shrinkage cracks.

- wide, longitudinal scratches along the reinforcement bars on the joist girder of the slab construction, along support pillars and stair cornices; these scratches indicate the carbonation of concrete and intensive reinforcement corrosion (e.g. figures 7 and 12 [12]) - Figure 4. 
a)

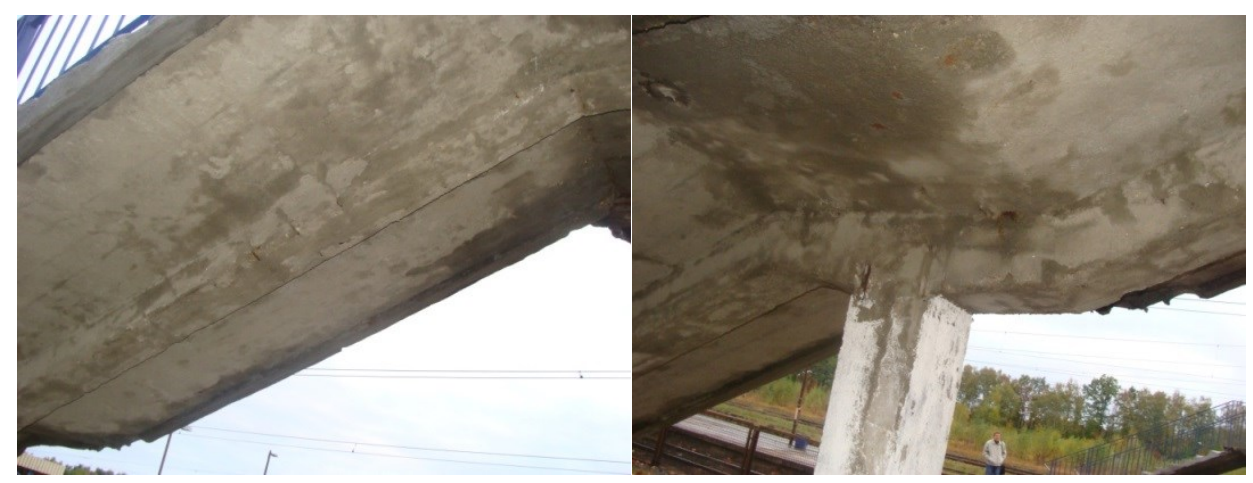

Fig. 4. a, b) Examples of destruction of the reinforcement cover.

- concrete cover delaminated due to the reinforcement corrosion (that is visible in all photographs, both of the bottom and the edge of the structure),

- vertical deflection of two supporting pillars, that is visible to the naked eye.

The design and construction errors described above compounded by improper maintenance have caused that the technical condition of the footbridge was defined as an emergency. The main errors in the maintenance work involved in the lack of effective protection against the permanent impact of rainwater on the structure. These rainwaters, with completely inefficient waterproofing and improper drainage have caused intense corrosion damage. Local repair attempts, that were undertaken, proved to be ineffective. Repair materials were applied locally, this solution does not ensure complete rainwater cut - off and effective connection of "old" (existing) material with repair material.

Rainwater, that migrates into the structures and partially flow down contained large amounts of dissolved chlorides and sulphides, which resulted in intensifications of the corrosion processes - this is especially visible in the thin desk slab and cornices. The hydrated deck slab (with a thickness of $7 \mathrm{~cm}$ ) did not have the proper frost resistance while temperature changes (through the 0 value). This caused the increase of cracks in the concrete deck that accelerated the process of local destruction of the entire concrete surface visible from the bottom of the footbridge and the bolts construction.

The construction of electric shock protective devices was incompatible with the technical conditions recommended for this type of protection of the bridges. The covers attached to the handrails were constructed as rectangular frames filled with steel mesh from the top, and by a steel sheet from the bottom. These covers did not protect the area around the electric traction. The height of the secured place over the traction network was about $1.70 \mathrm{~m}$. This solution did not guarantee the required width and height of the secured space over the cables of the electric traction network.

Due to the lack of structures enabling the access for people with disabilities, the footbridge, as a public facility, did not meet the requirements of articles 5 and 6 of the act of 7 July 1994 - Construction Law [14], to which the Regulation of the Minister of Infrastructure of 12 April applies 2002 on the technical conditions that buildings and their location relates [4].

The damage occurring in the structure of the footbridge constituted a direct threat both to the safety of the structure and the safety operation. The technical condition of the footbridge indicated an immediate threat of a construction disaster, therefore the footbridge was qualified for immediate exclusion from use. 
In the case of the second of the assessed facilities, the bad technical condition of the prestressed concrete beams of the piers was the result of numerous rainwater leakage - Figure 5. In the location of the leaks, cement paste was leached, which compounded by the carbonization caused the corrosion the prestressing reinforcement. These processes caused the delamination of the concrete cover, which fell off locally, while in other places during tapping of the construction with hammer, dull noise came out - Figure 6 .

a)

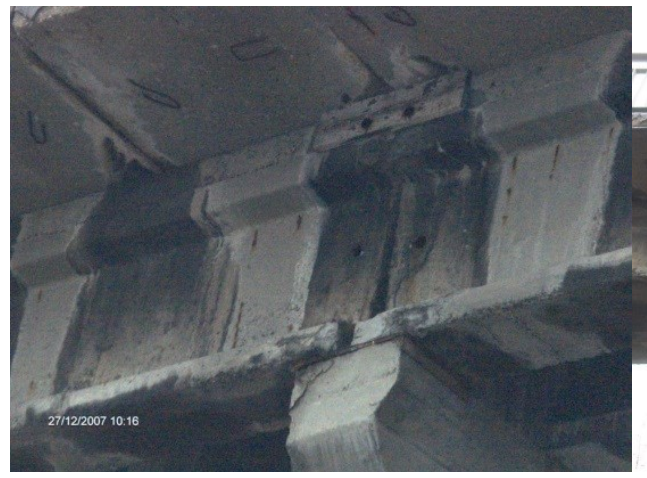

b)
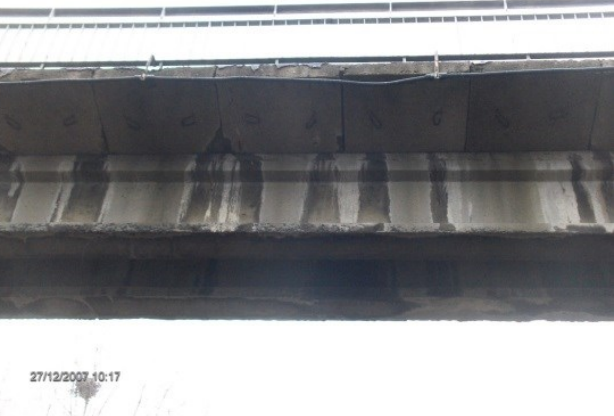

Fig. 5. a, b) Watermarks on the girders of the footbridge.

a)

b)

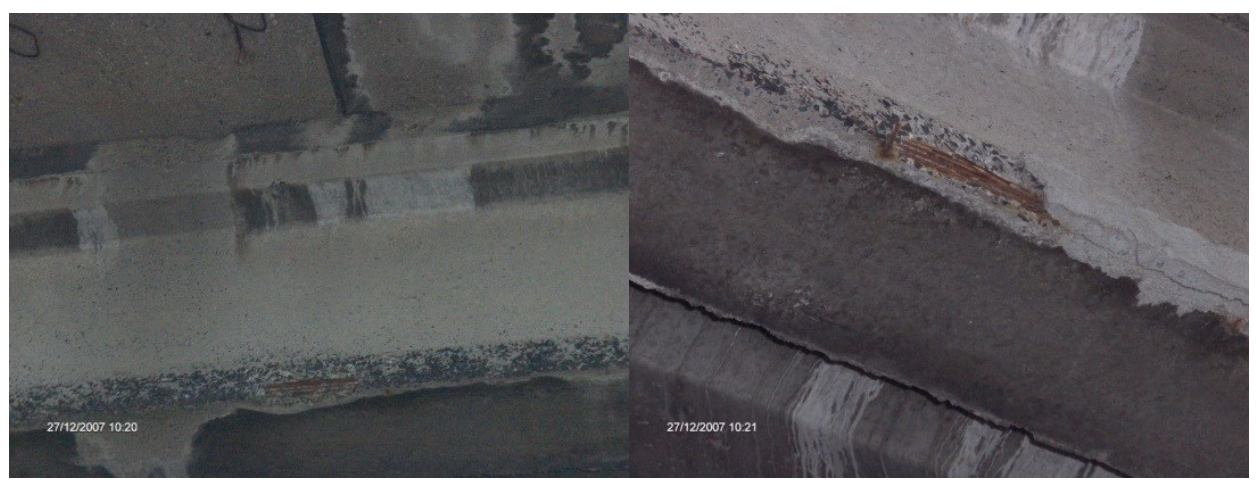

Fig. 6. a), b) Local corrosion losses of the reinforced concrete cover.

Locally, corrosion of the girder beams contribute to the rupture of some of the prestressing tendons - Figure 7. 


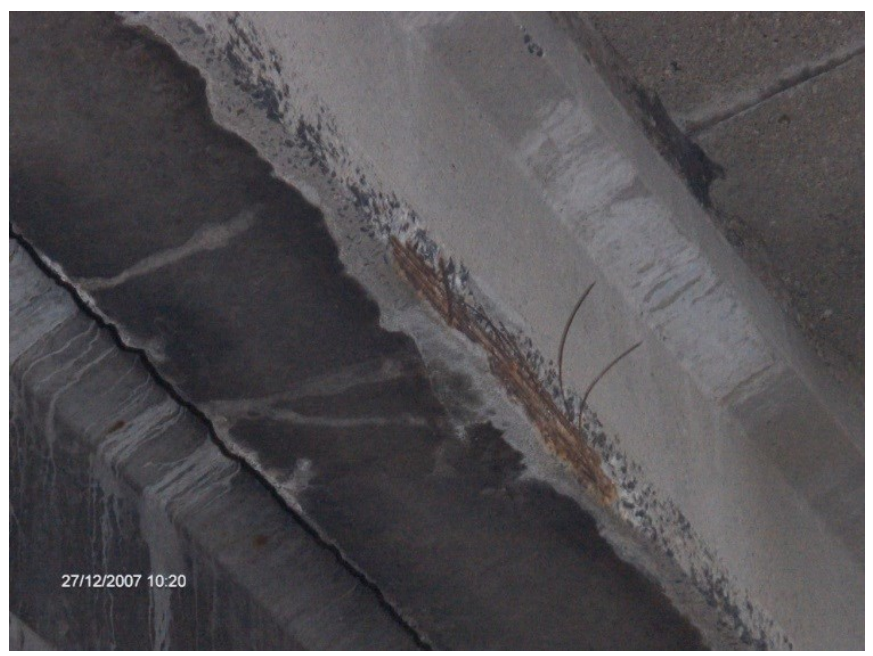

Fig. 7. Ruptured tendons of prestressed reinforcement caused by corrosion.

The stairs that descend from the Wola district side was made in the form of a steel structure made of rolled bars. The technical condition of this structural element was evaluated as good, only general corrosion of the surface was observed. The technical condition of the wooden stair steps was determines as bad, due to the cracks and cavities, that were a direct threat to the safety of the building users. On the other hand, the stairs to the Odolany railway station were made as a reinforced concrete structure. The state of this element was also determined as bad. Ineffective insulation have caused large corrosion damage both on the slabs and pillars of the footbridge [12]. The structure of the footbridge deck was based on seventeen reinforced concrete pillars, whose technical condition was evaluated as sufficient [12]. Rainwater runoff and carbonization of concrete have caused corrosion of both concrete and reinforcement. The concrete cover has been delaminated due to the corrosion of reinforcement, that is visible in the form of vertical scratches along reinforcing bars of the pillars. On several pillars, local defects of the concrete cover of the reinforcement were noticed, nevertheless even on unscratched pillars the delamination of concrete cover was observed - Fig. 8.

a)

b)

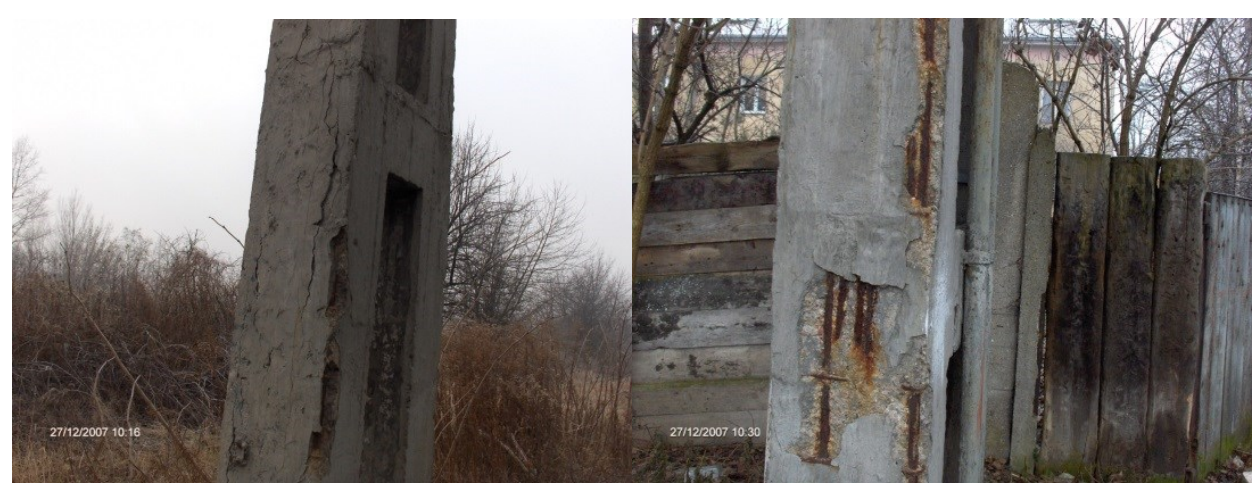

Fig. 8. Examples of cracks in concrete along the reinforcing bars of the pillars. 
All pillars were affected by corrosion, therefore, structural reinforcement of all pillars was recommended. Due to the great depth of concrete corrosion and significant general and pitting corrosion of reinforcing bars, all pillars of the footbridge had to be strengthened to achieve the design load - capacity of these elements, while taking into account the current norms. The surface of the footbridge was made of mastic asphalt, no insulation of the deck slabs was noticed [12]. Nawierzchnia kładki wykonana była z asfaltu lanego, nie zauważono jakiejkolwiek izolacji płyt pomostu [12]. Leaky surfaces arising out of the imprecise arrangement of the bituminous mass along the handrail, lead to the leakage of rainwater along the joints of the deck slabs and watermarks on girders. Moreover, leaks were created along unprotected expansion joints.

\section{Discussion}

The first of the described footbridges was built in 1954 in accordance with the regulations of 1946. Since then, the norms have changed several times, although the characteristic value of the pedestrian load was similar in subsequent norms. It can be assumed that the nature of the operational loads that should be carried by the structure of the footbridge, has not changed. Verification of the load capacity of the footbridge was completely pointless, because the object was qualified only for demolition. The degree of current degradation of the structure, large destruction of the concrete structure and a very high degree of reinforcement corrosion (loss of up to $30 \%$ of the bar diameter) indicated that the only load the bridge carried out was its own weight [12]. Due to the ineffective drainage of rainwater and the lack of effective waterproofing, the footbridge was subjected to rapidly advancing degradation and therefore it was recommended to demolish the footbridge. The major cause of the hazard on construction are errors in maintaining of the object, that consist essentially improper protection of the structure against the impact of rainwater.

In the case of a footbridge at the Warszawa Odolany Railway station, the poor technical condition of the structure is caused mainly by corrosion defects in the reinforcement of prestressed concrete girders [12]. The main reason for the weakening of the structure was the impact of rainwater, which caused accelerated degradation of prestressed concrete girders and reinforced concrete piers. It would be possible to reinforce the girders with, for example, carbon tape, although this solution would be very expensive and unprofitable. Due to the general technical condition, strength characteristics of the structural material, age and technical parameters of the object, comprehensive repair or modernization of the spans of the footbridge is economically unjustified. The cost of renovation would be comparable to the construction of a new facility, and the effect would be disproportionately lower.

The repair of pillars, whose reinforcing bars were subjected to corrosion, can be made by reinforcing them, e.g. by external reinforced concrete layer of at least $10 \mathrm{~cm}$ thick with additional reinforcing bars. Due to the general technical condition of the footbridge, it was recommended to exclude the bridge from use. In this case, as well, the main cause were maintenance errors, e.g. the lack of protection of the structure against the impact of rainwater. 


\section{Conclusions}

The determination of the causes and the degree of degradation of the embedded material are particularly important during the technical assessment of engineering structure. For this purpose, simple geometry measurements and specialist strengthen test of embedded materials are used. The article presents two cases of small engineering objects, which are footbridges that were excluded from exploitation [12].

The first footbridge, placed on $5.297 \mathrm{~km}$ of Łódź Fabryczna - Koluszki railway line, was the transition between platforms no. 1 and 2 at the Lódź Widzew railway station. Damages occurring in the construction of this footbridge, caused direct threat both to the safety of the structure and safety of use. Therefore, the footbridge was qualified for immediate exclusion from use. Modernization of this facility was unprofitable due to the necessity of replacement of practically whole construction. Additionally, it should be noted that the object constructed in the 1950s did not meet the applicable technical standards. Analysis of the technical condition has showed the incorrect layout of supporting pillars, that is impossible to determine, without testing under the loads.

The passenger flow traffic intensity using the services of the Łódź Widzew railway station is estimated at about 12 - 14 thousand people. Passengers, who switch to other trains would like to move from one platform to another as quickly as possible, using all available transitions. In this case, it was unacceptable, for any person, to have access to the footbridge in poor condition, which is why it was necessary to exclude out of use these footbridges effectively. In addition, it was necessary to protect both the tracks and the platforms against falling fragments of weakened concrete.

These recommendation according to the article 70 of the Construction Law [14], were immediately forwarded as information to Voivodship Inspectorates of Building Control. This obligation should be confirmed in the inspection report of the construction object [14]. Based on special survey [1], construction supervision issued a decision to dismantle the footbridge as a matter of urgency.

The second of the presented in this paper facilities is footbridges at the Warszawa Odolany railway station, that was already excluded from use. The facility manager wanted to specify the scope of works in order to restore the facility for use. Carried out site inspection and test pits indicated, that until the building has been reconstructed, it should still be excluded from use. It was also recommended to periodically (at least once every two weeks) check the condition of the object marking and safety devices. Despite the exclusion of the footbridge from use, the safety nets were removed by unauthorized users.

Presented footbridges over the railways, were excluded from use, due to the maintenance errors. Footbridges, as structures subjected to low loads, do not undergo technical wear and tear due to the number of load cycles. The examples, that have been presented in the article, show how important their proper design for reasons of usability is. In projects of this type of buildings - reinforced concrete footbridges - attention should be paid to the use of appropriate thickness of reinforcement bars. This should include the aggressiveness of the environment and currents straying from traction. Another element that determines durability is proper maintenance of the facility, during which special attention should be paid to emerging rainwater leaks. 


\section{References}

1. Załącznik do Zarządzenia nr 14 Generalnego Dyrektora Dróg Krajowych i Autostrad z dnia 7 lipca 2005 roku Instrukcje przeprowadzania przeglądów drogowych obiektów inżynierskich [in Polish]

2. Załącznik do zarządzenia Nr 48/20014 Zarządu PKP Polskie Linie Kolejowe $\mathrm{z}$ dnia 1 grudnia 2016, Instrukcja utrzymania kolejowych obiektów inżynieryjnych na liniach kolejowych do prędkości 200/250 km/h Id-16 [in Polish]

3. https://www.gunb.gov.pl/strona/katastrofy-budowlane

4. Rozporządzenie Ministra Transportu i Gospodarki Morskiej z dnia 30 maja 2000 r. W sprawie warunków technicznych, jakim powinny odpowiadać drogowe obiekty inżynierskie i ich usytuowanie [in Polish]

5. L. Więcław-Bator, W. Moćko, R. Chmielewski, L. Kruszka, Roads and Bridges - Drogi i Mosty, 15(4), pp. 315-328 (2016)

6. https://www.wprost.pl/swiat/10111208/tragedia-na-florydzie.html access on 20.12.2018

7. http://wiadomosci.gazeta.pl/wiadomosci/7,114883,23806702,katastrofa-mostu-wgenui.html access on 20.12.2018

8. R. Chmielewski, S. Sancewicz, P. Muzolf, Problemy Kolejnictwa, 174, pp. 7-18 (2017) [in Polish]

9. A. Wysokowski, Trwałość mostów stalowych $w$ funkcji zjawisk zmęczeniowych i korozyjnych (Instytut Badawczy Dróg i Mostów, Studia i Materiały, 53, 2001) [in Polish]

10. A. Wysokowski, Zmęczenie i korozja - wyznacznik trwałości eksploatacyjnej mostów stalowych, Mosty stalowe. Projektowanie, technologie budowy, badania, utrzymanie (Wrocławskie Dni Mostowe, Wrocław, pp. 369-379, 2008) [in Polish]

11. H. Zobel, T. Alkhafaji, M. Wróbel, Mosty, 2, pp. 40-54 (2007) [in Polish]

12. R. Chmielewski, L. Kruszka, Ekspertyzy, opinie techniczne z zakresu budownictwa, (WAT, Warszawa, 2005-2018) [in Polish]

13. PN-S-10042:1991 Obiekty mostowe. Konstrukcje betonowe, żelbetowe i sprężone [in Polish]

14. Ustawa z dnia 7 lipca 1994 r. - Prawo budowlane [in Polish] 